\title{
Literature, Exhibitions and Communication: A Conversation
}

\author{
Heike Gfrereis, Helmut Neundlinger, \\ Johan SCHIMANSKI \& ULRIKE SPRING
}

\begin{abstract}
Informed by her competence in literature and the theory and practice of exhibitions, Heike Gfrereis is Head of the Museum Department at the Archive of German Literature in Marbach, and curator of many literary exhibitions. Helmut Neundlinger, curator of the W. H. Auden Memorial Museum in Kirchstetten, is a writer, researcher and critic working at the Center for Museum Collections Management at the Danube University Krems and the literary collection of Lower Austria. The following "exchange of knowledge" between them and two researchers in the TRAUM- Transforming Author Museums project took place in Oslo in 2019. We discuss the desire to exhibit literature and not only biography, how one can free oneself from objects and how objects can create freedom, how to unlearn received notions of literature, the importance of interaction and play, what can make authors difficult to exhibit, and the economic realities of exhibiting literature.
\end{abstract}

Keywords: literary exhibitions, literary museums, writers' houses, author museums, exhibition practices, W. H. Auden

\section{Communicating Authors or LITERATURE}

Johan: You have both had quite different experience of curating literary exhibitions. Heike, you have worked with exhibitions for museums and houses of literature, whereas you Helmut have worked with an author's home museum. We would like to begin by asking you, from those different experiences: what is the most important facet of working with an exhibition for a museum for you?

Heike: I have curated literature exhibitions for more than 20 years, altogether about a hundred exhibitions, small and large permanent ones. These have not been in authors' homes, but in literature houses or museums like the Museum of the Archive of German Literature in Marbach. Not making exhibitions in authors' homes means dealing with architectural spaces not connected to the authors. The first exhibition I made, with my students in the 1990s, was about a Swabian author, the Romantic poet Eduard Mörike (1804-75). The exhibition was called Mörike Put on the Shelf (Mörike ins Regal gestellt), 


\section{Heike Gfrereis, Helmut Neundlinger, Johan Schimanski \& UlRike Spring}

because my intention was to stage literature - not the author, but literature and the text. The exhibition was in a town museum near Marbach, Ludwigsburg, the birthplace of Eduard Mörike. Marbach is the home of the Schiller-Nationalmuseum and of the Museum of Modern Literature - two major museums - and the German Literature Archive, and I made this exhibition with my students so as to critique the exhibitions there, because they usually presented ensembles, constellations of objects put together in order to show the "ghost" of the author. I read because I love literature and texts and fiction, and not because I love the author. So for me literature is the most fascinating facet of every literary exhibition.

Helmut: For me it's the other way around! I've made only one exhibition as main curator, the W. H. Auden memorial house in Kirchstetten in Lower Austria, in cooperation with a very skilful set designer, Peter Karlhuber. We had to address two things - the author and the architecture of the house. This sounds quite different from what Heike does, but I think that we have something in common: our love for literature, for texts. It helped a lot in my case that Auden did not only live in the house, but also dedicated one of his most important poetry cycles to the house (included in a book about the exhibition, Neundlinger 2018). He dedicated the altogether twelve long poems to one room each. This created a resonant space in which to make the exhibition.

At the same time, we have only two of his rooms left, because the house is still lived in by a family. You have normal, ordinary life going on downstairs, and there are constant relations between the inside and the outside, or between what we could call the museum space and the everyday life of the community. I would describe the museum as an enclave, an enclosure. The town Kirchstetten calls itself a poets' community (Dichtergemeinde), because not only English-American poet W. H. Auden (1907-1973) lived there, but also Josef Weinheber (1892-1945). The latter was an Austrian poet who lived in the first half of the twentieth century and had a very problematic political inclination to Nazism. He killed himself in 1945. Auden came to Kirchstetten in 1957 and 1958, long after Weinheber's death, but wrote a poem about him. So there are many relations you can build on in Auden's literature, not only on his life and his biography, and from that perspective we might say there is a bridge between Heike's approach and ours.

Ulrike: A constant topic in the TRAUM research project was the dominant presence of the author in literary exhibitions, not only in authors' homes, but also in literary museums. In a way this is surprising, since the author is only given an exhibition because of his or her works. Is it so much easier to exhibit an author's biography and life than her literature?

Heike: I think the convention that to show literature is identical with showing the author comes from the celebration and cult of the Author.

Johan: The cult of the genius?

Heike: Such a cult implies that the written word of literature is something like the written word of the Bible. In the eighteenth century literature ceased to be a part of religious life, and to fill this void, people grasped the nearest concrete thing to literature, and this was the writer. I believe this is still a very dominant convention, which explains why so many visitors want to see the author, not the literature, and why many museum funding bodies and steering committees also support such a biographical approach. You are always 
confronted with this desire and hope to grasp the author's ghost.

Ulrike: What unites both of you is the love for literature and for texts. But you work with different museum genres: literature museums and an author's home. Is it easier to focus on literature in a museum that is not associated with the author's life? How much does the context determine whether the author or her work and literature are at the centre of the exhibition?

Heike: What interests me is that in the author we have a person who sits all day at a desk and concentrates on writing. So a special form of living habit is associated with this genre of person. Nothing happens, which is very good for the progress of the author's work. This is fascinating. We once made a little exhibition together with the Hungarian author Péter Nádas (b. 1942), and he wanted it to be about the "boring life" of authors. For me this points to a major tension in literary exhibitions.

Helmut: In Auden's tendency to self-staging the answer to boredom is ritual. You practice a ritual life because it is "naked", and make a religious cult out of it. This is why we put the schedule of Auden's working day on a wall of the exhibition. We do not know whether he kept very strictly to this schedule, or if he varied it, but it has the status of a performative transfer from the past. It was important for him to tell the world, and even the afterworld: "Look, that's how I worked, that was my disciplined way of carrying out my business." For me, it is here that it starts to get interesting, because reflection and self-staging become mixed.

Perhaps the French literary theorist Gérard Genette would have called Auden's schedule a "paratext". Auden produced a paratext about the way in which he structured his work. As a literary scholar, it is natural for me to integrate this document in the exhibition, and let people have their own thoughts about it. They could say: "OK, he says he would get up at eight oclock, and finish his work at six with a whisky, or a brandy, or something similar. All right, we may believe him, but then, perhaps it wasn't true." So you create a space of imagination around the author, or rather, the author creates a space of imagination around his work. This is what I would call a paratext.

Heike: And you create a space of meanings. This is the interesting question: If objects are involved in a text, can they function as literary signs? A glass for example can be given meaning with reference to the text, and become a form of epitext or paratext. Seeing objects in this way, we can get an understanding of on one hand the relationship between meaning and fiction, and on the other hand the reality of a text.

\section{MUSEUMS AND ARCHIVES}

Helmut: Heike, you are also strongly involved with an archive. Do you think we deal with such documents and objects in a different way in an archive, when compared to a museum?

Heike: The way in which an archive - every archive - collects, always has the museum in the back of its head. The author's estate contains papers and manuscripts. My colleagues often ask the author: "Do you have something which is very important for you?" Say, in the case of the Austrian author Barbara Frischmuth (b. 1941), her garden hoe. What happens here is that the author says it is meaningful, and colleagues from the archive think we want to show meanings and their own favourites. So you can find none of the silent remains in the archive.

As a curator, you also want to find the piece without meaning. You know that it will 
often be thrown away and not included in the archive, because the archive collects with regard to the meaning of things, whereas the museum should fight these meanings. So in some cases we are kill-joys, because we don't play according to expectations. We show things without investing them with meaning, or we even deconstruct their meaning. We do not create an aura out of this atmosphere of meaning.

Helmut: The Auden collection was given to our archive, the Literary Archives of Lower Austria, in the 1980s. At that time, the archival work was not very professional. They took in nearly everything, also things you would not collect today. One object was huge and I didn't even know what it was called. It was a big glass standing in a kind of food rack. But then, Peter, my colleague, the designer, came in and said, "Oh, it's a Weinheber [a wine syphon]." So with this object we could integrate the poet Weinheber, Auden's neighbour, into the exhibition narrative, only because for some reason Auden had collected this strange object. Peter built a glass case especially for this object. It depends on the visitors whether they know what a Weinheber is or not, but those who know what it is and know about the author, often start to laugh, because this is a complete deconstruction of Josef Weinheber, who is made present as a rural object. However, I would not have discovered this on my own and needed my colleague to tell me about it. We did not think about producing a special meaning or something like this, we just had fun with this object.

Heike: This curatorial work runs counter to the work of an archive that tries to clarify meanings and attributions as precisely as possible and reduces ambivalence. The kind of exhibitions that I find attractive reawaken these ambivalences.

\section{THE FREEDOM TO CREATE}

Johan: Could I ask more in continuation of the previous question about the kind of exhibitions you have made? You are very free in a sense. You do not have to follow the biography and author, and you do not have to evoke the presence of an author. You can look at many authors, you can look at a motif rather than an author, you can look at a period or school of authors. You could even look at readers instead of authors - at practices of reading.

Indeed, you could almost be free, in a writer's house museum, to actually look at the biography. A writer's house museum brings with it very specific problems of how to present biography. Auden's house in Kirchstetten, for example, relates primarily to the late part of his life, and mostly to when he is in Austria and not in New York. The home is more about the body and daily routines than about a life story. But on the other hand, Helmut, you do also take the freedom to bring in both the literary text and his life story into the exhibition.

Helmut, you also hint that Auden fashioned his house in a poetic way, and that the house in fact has become part of the literature. This is a point that Harald Hendrix (2008) has made about many authors: that they know that their houses are going to become museums, and they actually plan them that way.

So the question would be: how do you feel about these freedoms, and when you're working with an author's house, how can you actually also take some freedoms and free yourself from a purely biographical perspective?

Heike: I'm very happy about this freedom, because it means you can create freely, but there is also a disadvantage in regard to exhibiting literature, because you are without any corpus. You search according to criteria, for example when we only show objects from 
the Marbach archive. In other cases you are free to be expansive. I have to make an exhibition about Hegel within the next two weeks and we have no estate, and you sit there and think: Why the hell Hegel? Which work? His Lectures on Aesthetics? Oh no, it's too large. The Phenomenology of the Spirit? Oh God no, it's too heavy. I would be very happy if we just found one green box of Marbach manuscripts and could say, "Oh, we'll show this." Or that we could find Hegel's desk and exhibit this. This lack of objects is the disadvantage of this freedom. ${ }^{1}$

Often we have to make exhibitions because of the German tradition of celebrating writers' anniversaries. The paradigm of these author exhibitions is the great narrative, the grand récit. It is more appealing to imagine that writers concentrate on one thing in particular: making literature. This means that the emergence of their literature is a permanent revolution of life, a machine for explaining reality or even for annihilation. I find it very exciting: what happens when you shine their texts into their estates, and what happens when you look at their desks from the perspective of their texts? And: What happens when you bring these texts into space and think in space? The fewer originals one has, the more one depends on concentrating on the body of the texts and unfolding it in the exhibition spaces. It can therefore be a great advantage to exhibit literature without an archive. On the other hand, the archive is of course also a great hermeneutic driving force, because one is constantly confronted with unexpected or mysterious and above all very concrete things. Archives give literature an irrevocable reality and present.

Helmut: As a visitor of your exhibitions, I would call it a Wittgensteinian approach, because you always encourage the people to use the texts or to use the objects. It's not always a text, sometimes it is a picture, or sometimes an object from the archive, but your approach is more or less the same when Wittgenstein in his reflections on language games ("Sprachspiele") says, if you want to know the value of something, you have to turn it around, you have to try out something with it (Wittgenstein 2009). I think that is the best approach, because after all, walking through an exhibition is not exactly the same as reading a text; it is more like writing a text. You and I have had these inspiring exchanges for the past one and a half years, in which I have asked you: who is the author, who speaks in your exhibitions? For me you are kind of a writer, an author, a poet.

Johan, you asked about the forces, or the kind of prison, a memorial home puts around you. My major advantage was that we did not create a new exhibition, but re-wrote an old exhibition. We had always in mind how the room had looked, how the exhibition had worked before, and tried to use this opportunity to respond to the exhibition as it had been before. The previous curators did what they could according to their time and with the means they had at their disposal. Our exhibition is not a critique of the older one, but we tried to play with it, also taking it as a blueprint. We had the freedom to produce a new narrative about Auden in Kirchstetten.

Ulrike: If you were to transfer Heike's approach to exhibitions into the Auden house, would this work, or would it alter or challenge the idea of how a Memorial House functions?

Helmut: I would at least like to invite Heike to do a small intervention or something like that, because it is not really a question about transfering things from the past, but creating 
a method out of your object. For instance, it would be nice to show Heike Auden's run-down car, a Volkswagen beetle, and ask her: How would you "read" this object? And how could we connect the object with your reading? This is what I would call phenomenology: it was Husserl (1985) who said that 'the object is the method'. If we take Heike's exhibition Lachen Cabaret (Laughter Cabaret), you look at the things, and you reflect on what we can make out of them, out of the objects, out of their materiality, out of the questions that arise from the material. If you were to come to Kirchstetten, Heike, you would create your own ideas about what the room or even the area could be like: How could we expand Auden to the whole of Kirchstetten? What should we do with certain objects? For example, we have a very difficult object, a car - a Volkswagen Beetle - which is in a very bad state, but on a symbolic scale, it's one of the most important objects connected to Auden's house. Indeed, it is one of the most crazy objects there, because of the many stories around it.

Heike: I think the fascinating power is to turn things into signs and the other way around, so you can play with them and create your own alphabet. You can show manuscripts as artificial objects. You can try to find out the grammar of the things, and you can make everything into a thing and everything into a sign, and the other way around. And this is what is fascinating about making exhibitions. That's the problem with Hegel: we have no things and only a few material texts in Marbach. We have no material textures and no material beginnings and tracings of thinking. Therefore, one has to get into thinking by detours and turn his printed texts into such initial objects of thinking. Or simply invent such objects.

\section{HOW TO EXHIBIT LITERATURE}

Johan: But coming back to this question of wanting to exhibit literature, and perhaps challenging people's expectations: they expect the author and you give them literature. How do you exhibit literature?

I was thinking of the Balzac museum in Paris, the Maison de Balzac, in what used to be his home. The room in which the French author Honoré de Balzac (1799-1850) wrote, is a place where literature happened - though the current fashion of exhibiting, for example, the author's bathroom (e.g. in the Ibsen flat in Oslo), can also point to a place where literature happened for the author, since authors can lie in a bath or go to the toilet and think about their next sentences. In the present exhibition, the first room is filled with a number of busts of Balzac, made by sculptors - and obviously literature also happened in his head. Then there is a room with different manuscript versions of the novel which he had been working on, and that is also a place in which literature happens - very close to his body. Then there's a room with many images of characters from his books, and that is also a way of exhibiting literature. And then there are bookshelves with his books, which are also literature. You also see quotes from his texts, which are also literature.

If you go to an exhibition for children, it will also be about literature: not about the books or the texts or the places in which they were written, but about the world depicted in the texts. This is usual for literary museums about children's literature. Also, the house itself might be part of the literature, depicted in the literature (as happens in non-fictional forms of literature, such as lyric poetry).

How do you deal with these many different ways of exhibiting literature? 
Heike: Playing with the many different ways of showing literature indicates the richness of the genre. You can show the structures of literature, which are the first visible quality of a literary text. You can do this through close reading. You take your pencil in your hand and mark something with red and blue and yellow, and then you have a very visible and very showable structure of the text.

In addition you have this very rich area of paratext and epitext. You have forms of fantasy and imagination, and also the transfer and transformation of the world into the text.

Helmut: The examples you mention tell us a story that circles around the question of how to exhibit literature. You could also say that you cannot really exhibit literature, but that you can exhibit the production or reception of literature. I do not think we have to choose one specific way of doing this, because the examples you mentioned address different kinds of visitors: specialists, children, people who are interested in biographies of authors, rather than in their works - which is also legitimate.

Sometimes the setting defines what comes out of the exhibition, and sometimes you are allowed more freedom. In Heike's exhibitions you are always nicely confronted with a very creative approach to literature and having to find your own way through. An exhibition should work for people of all ages, be it from six to a hundred. It is only a matter of whether somebody is open to literature, or to biography; if he or she is not open to either of these, it is wasted time in a way. Sometimes you can reach people who are not very interested - that's a victory but in general I think the challenge is to get something out of the material, at the very least.

\section{Playing With literature}

Ulrike: We have mentioned children's literature. There are many theme parks that exhibit literature by simulating a literary world, and where the visitor can interact with the protagonists of the works - they literally talk to you. Examples include Moominworld in Naantali, Finland (not so much the Moomin Valley Park in Hannō, Japan, which is primarily intended for adults), which is based on the Moomintroll books by the Finnish author Tove Jansson (1914-2001), or Astrid Lindgren's World in Vimmerby, Sweden, based on various books by the Swedish author Astrid Lindgren (1907-2002).

Helmut: One could say that they re-enact literature.

Ulrike: It is interesting that it is accepted to interact with literary worlds and their protagonists when you are a child, but no longer when you grow older. Well, there is the example of the Buddenbrooks House in Lübeck, which exhibits a fictional house and scenes from the fiction of the German author Thomas Mann (1875-1955). But in general, as one grows older, the focus goes from living in literature to literature becoming a part of your head.

Heike: Yes, this is because adult visitors are not like children, ready to let themselves be involved. Adults simply have more inhibitions. The Buddenbrooks House is the setting of a novel, but many visitors think that it is a real location. They do not see the difference between fiction and reality. I think children see the differences when they interact, and they also are able to turn words into signs and things. They have no problem if they cannot read handwriting, for example in a manuscript. Adults have a problem. They want me to tell them what the meaning is, and why they should read this. 


\section{Heike Gfrereis, Helmut Neundlinger, Johan Schimanski \& Ulrike Spring}

Helmut: Adults believe in cultural competence when they go to an exhibition, and it is a problem if you give them a text or an object that they cannot decode straight away. But I also think that this comes out of the tradition of the cult of the author, because if you are a grown-up person, you have been to school and are told how to read literature. It is considered to be elitist, so you may even think you are not able to reach it or to touch it, and it becomes completely impossible to play with it.

Heike: The didactic programme of teaching literature in schools does not address ambiguity, and this means that you have a permanent feeling of reading things the wrong way. Perhaps this is one of the reasons why adult visitors and children treat exhibited literature differently.

Helmut: Yes, it is not only the text, but also the reception that is canonised. This is something we have to demolish. We should at least deconstruct it. Because then literature has the opportunity to become alive again.

Heike: We both make exhibitions against teachers!

\section{From PASSIVE MUSEUMS TO INTERACTIVE CENTRES}

Ulrike: In Norway it has in recent years become popular to create author centres, something which we have not seen much in other countries. One main audience, and main target group, is school children. One idea behind this genre is to engage with literature, to communicate it in various forms, or to learn from literature, but also from the authors. These centres use interactivity, re-enactments, games etc. as their main tools. Norwegian museums usually have schools as their major target group, and this may also explain the popularity of these literature centres.
Johan: Such centres often have modern or even signal architecture, contributing to place-branding. They sometimes share their buildings with libraries. They function as community centres and more generally, as cultural hubs.

Heike: I know of one case in Germany, the Centre of Literature at Burg Hülshoff near Münster - birthplace of Annette DrosteHülshoff (1797-1848) - which has attempted something in this direction. But the approach in Germany is to make exhibitions at archives or in libraries. In Marbach we want to find a way to make the museums more accessible for people and pupils, giving them an opportunity to be interactive. The museums should not only be places of passive reception. As it is now, you have to renew exhibitions a year after they have opened, because it is the event, and not so much the exhibition itself, that acts as an attractor for visitors. So I think we have to think more like the centres in Norway.

Helmut: One object in our exhibition is a TV documentary about Auden in Kirchstetten made in 1967, which was done by the Austrian public broadcasting station ORF as part of a series called The Austrian Portrait - Auden was made into an Austrian! In one scene he's standing near his desk in his writing room, and we have placed our video screen exactly at the same position. He just answers questions and looks a little stiff, because it's the sixties, and you hear the voice of the interviewer. If we ever were to produce a digital version of our exhibition, I would like to have Auden as an avatar walking through the building and saying: "I'm W.H. Auden and I'm very glad that you visit me. Come in and I will show you my house. This is where I wrote my most famous texts during my late years. Don't look at the bottles, I forgot to carry them out," and so on. This would be an opportunity to react 
to the transformation of perceptual habits; young people would not have any problem with immersing themselves in an Auden avatar game. You would of course have to take into account their forms of perception and narration, but if you gave them a very strange looking old guy - once Auden said his face looked like a wedding cake left out in the rain - they would be interested and they would follow him, even if he was presenting them the completely boring house of an author who had been dead for 45 years.

Johan: The tendency to interactivity signals an ongoing democratisation of museums. Of course, literary museums have always been associated with a form of wider access to the author, going beyond just reading the books. In the beginnings of the cult of genius you would visit even the house of the living author. But now it seems there are attempts to make these museums even more accessible on many different levels. This means that many different new exhibition forms and experiments with these forms are appearing.

Does this also mean that we have to become more aware of the whole spectrum of what an exhibition of literature might be? For example, if we go to a bookshop, you also see an exhibition of literature, if you go to somebody's home, the bookshelves are an exhibition of literature. Not only archives or museums or author's homes make literary exhibitions now, but also local and national libraries. Libraries of course often exhibit literature in the form of books themselves, because those are the objects they have in their collections. Is there a connection between this kind of democratisation and new forms such as the Norwegian author centre genre? Is this a way of making literature more of an everyday experience?

Heike: I think the plurality of literary exhibition practices that is not bound to specific institutions, the unrepresentative forms of exhibition, could present a possibility. In some exhibitions I have the impression that curators fear this democratisation. They try to stick to the cult of the original, the famous aura of things, or they want to hide behind an objective narrative. In Marbach we always have to discuss whether it is necessary to show the original in every single case, because of the difficulties with exposing originals to temperature and light - the famous "50 lux". The exhibition space is dark and cold, and for visitors perhaps there are more comfortable ways of learning to live with and in literature, to read books perhaps. Libraries are places where you can read, where you can learn to read books.

This morning I visited the (old) Munch Museum in Oslo and was very surprised by it. When it comes to exhibitions, art museums are the opposite of museums of literature, because they can show the artwork - the object in itself - to visitors. In the case of literature we show in most cases things which refer to the imagination. They are not the real thing themselves, like an artwork. Our objects are only substitute objects. The Munch Museum however not only shows Munch's pictures, but has similarities to an exhibition of literature. The pictures hang on the wall, but as a visitor you get the impression that they are not the main thing. The main thing is the epitext, the paratext and pedagogic space of the museum. Interestingly, I was given no information about the pictures on the walls, and there were no white cubes, only a landscape in which to guide pupils, which the visitors perhaps are in this case. I think this arrangement constitutes a form of interchange between art museums and museums of literature.

Some years ago the curator was the person who gave meaning to the object. I think today 


\section{Heike Gfrereis, Helmut Neundlinger, Johan Schimanski \& UlRike Spring}

100 that curators are persons who bring people together through objects, and no longer add their own interpretations to a room or a picture.

\section{EXCLUDED LITERATURE}

Johan: Where democracy is concerned, it is important to realise that we are fixed in a canonical tradition. We have a canon of those we want to exhibit and we're very selective when creating that canon. So we have to ask: What makes exhibiting authors and literature difficult?

This might be a question of how to exhibit literature which is controversial. It is not quite the same as sitting at home and reading it, safely within the private sphere; exhibitions are of course part of the public sphere. Some authors have become questionable. The famous example in Norway is Knut Hamsun (1859-1952), who has an author centre, Hamsunsenteret, dedicated to him near his childhood home on Hamarøy. Hamsun affiliated himself to Nazism before and during the occupation of Norway, as Weinheber did in Austria, if in a different way.

Then there is the question of authors who are not part of the canon, but who it would be interesting to exhibit because they are precisely a part of the wider field of literature. I refer here to authors who do not live in one place, who are mobile, travel writers and migrant authors; young authors who are not yet well-known, unsuccessful authors; and so-called "bad" authors, authors of popular literature. How do you work with these kind of marginalisation and difficulties, with this absence of communication?

Helmut: The same goes for literary history in general. Literary history has always produced a list of names that is white, male andheterosexual.
It is important to deconstruct this dominant narrative of what literature has been. One of the most interesting aspects about the history of the Auden Museum is that it would not exist but for the commitment of Peter Müller, cofounder of the International Auden Society in the late 1970s, and a homosexual himself, who lived in the neighbourhood. He visited Auden when he was in his early twenties, and not only did he live in the Austrian countryside in the late sixties, but homosexual activities between adult men were forbidden until 1971, so he was always in danger. And there was this man, Auden, from America or Great Britain, living there with his male partner, Chester Kallman (1921-75). They did not have sex with each other, but their lovers came for visits. This way of living was one of the main reasons why this young guy, who also noticed that Auden was a great poet, wanted to save his Austrian heritage: the building, the papers and so on.

This tells me so much more than the story of a queer writer. It is also a story about what Austria was like in the sixties or seventies, and why there was this interesting tolerance towards the stranger who was obviously gay, but who also sang in the local church choir. $\mathrm{He}$ sat in the church every Sunday, enjoying the service. The female organ player - she was a very young lady then - always comes to our presentations and tells us about what it was like to play the organ next to Auden singing very loudly, and sometimes not all that correctly.

This points to an interesting aspect of this form of literary exhibitions, because it tells you something about cultural heritage, about social and political situations, about what is seen as normal behaviour and what is not, and so on. We may call authors outsiders, so I think the museum gives the perspective of outsiders on society. Not only with Auden, evidently, because he always was an outsider, but there 
are many others where we could find similar stories.

Heike: Exhibitions of literature are not the easiest way to work with literature: reading is easier. At the same time, one of the major advantages of literary exhibitions is that you can reflect on the conditions of the production and reception of literature.

Perhaps we should also discuss the economy aspect of exhibitions. In the case of the German Archive of Literature we must make money with our exhibitions, reaching specific targets. We must have black and not red numbers in our accounts at the end of the year. At the same time, it is very important not to make only the big exhibitions in order to reach those targets, but also these more uncomfortable exhibitions about the queer and unknown writers. I think it is important to make something which goes against a canon and against the conventions of the genre.

I would like to open the museum to all people, without entry fees. After all, in the cultural sector, you cannot calculate as you do in the free economy.

This conversation was made possible by funding from the Research Council of Norway through the research project TRAUM - Transforming Author Museums (project number 251225).

\section{Notes}

1. See https://www.dla-marbach.de/museen/ wechselausstellungen/hegel-und-seine-freunde/ (seen 13 January 2020).

\section{REFERENCES}

Hendrix, Harald 2008. "Writers' houses as media of expression and rememberance: From selffashioning to cultural memory." In Harald
Hendrix (ed.). Writers' Houses and the Making of

Memory. New York: Routledge, 1-11.

Husserl, Edmund 1985. Die phänomenologische

Methode. With an introduction edited by Klaus

Held. Stuttgart: Reclam.

Neundlinger, Helmut (ed.) 2018. Thanksgiving für ein Habitat: W. H. Auden in Kirchstetten. St. Pölten:

Literaturedition Niederösterreich.

Wittgenstein, Ludwig 2009. Philosophische

Untersuchungen $=$ Philosophical Investigations.

The German text with an English translation by

G. E. M. Anscombe, P. M. S. Hacker \& Joachim

Schulte. Rev. 4th ed., edited by P. M. S. Hacker \&

Joachim Schulte. Chichester: Wiley-Blackwell.

Heike Gfrereis, dr. phil., Head of the Museum Department

heike.gfrereis@ilw.uni-stuttgart.de

Deutsches Literaturarchiv Marbach

Schillerhöhe 8-10

DE-71672 Marbach am Neckar, Germany

https://www.dla-marbach.de/ueber-uns/

mitarbeiterinnen-und-mitarbeiter/museen/

Helmut Neundlinger, dr. phil., scientific staff

helmut.neundlinger@donau-uni.ac.at

Zentrum für Museale

Sammlungswissenschaften

Donau Uni Krems,

Minoritenplatz 4

AT-3500 Krems, Austria

https://www.donau-uni.ac.at/de/

universitaet/organisation/mitarbeiterinnen/

person/4295262437

Johan Schimanski, dr. art., Professor

johan.schimanski@ilos.uio.no 
Heike Gfrereis, Helmut NeUndlinger, Johan SChimanski \& UlRike Spring

102 Department of Literature, Area Studies and European Languages

University of Oslo

P.O. Box 1003 Blindern

NO-0315 Oslo, Norway

www.hf.uio.no/ilos/personer/vit/johanhsc

Ulrike Spring, dr. phil., Associate Professor

ulrike.spring@iakh.uio.no

Department of Archaeology, Conservation

and History

University of Oslo

P.O. Box 1008 Blindern

NO-0315 Oslo, Norway

www.hf.uio.no/iakh/personer/vit/historie/fast/

ulrikesp 